\title{
M\&A Open Innovation, and Its Obstacle: A Case Study on GCC Region
}

\author{
Wardah Bindabel
}

Finance Department, Business Administration College, Prince Sattam Bin Abdulaziz University, Riyadh 16278, Saudi Arabia; wardahaldabel@gmail.com or w.bindabel@psau.edu.sa

Received: 13 August 2020; Accepted: 3 November 2020; Published: 10 November 2020 updates

\begin{abstract}
Considering the effective growth in challenges and an urge in establishment for sustainable business, companies trading globally are inclined towards the implementation of highly efficient cross-border reallocations of revolving capital. The prominent objective of this research paper is therefore the clear identification of the active key attributes and specifications of all strategic measures for efficient sustainable cross-border mergers and acquisitions (M\&As) of the Islamic companies in the Gulf region that are keen to engage with the non-Islamic companies across the globe. This paper also explores the paradigm of culture, in its different manifestations, it was and still is a primary factor of creativity. This study also focuses on building some better understanding of the role of "Culture for Open Innovation Dynamics." Initially, since the need to interpret community, that can also influence the dynamics of open innovation, has sharply increased, the research addresses open innovation dynamics and its significant concerns related to cross border mergers and cross culture ventures of firms and organizations. The researcher purposively selected 15 financial institutions from the selected Gulf Cooperation Council (GCC) countries. Semi-structured interviews were conducted with 40 key individuals including Board of Directors (BOD) members, lawyers and the Shariah scholars involved with three Islamic banks and two Islamic insurance companies in GCC. The findings indicate a consensus among the respondents regarding how the Shariah corporate governance principles can present barriers for cross-border M\&As. Key obstacles to the success of cross-border M\&As between the Islamic and the non-Islamic companies include the Shariah compliance, weak systems of disclosure, dependency, corruption in compliance, having family members on the Board, weakened communication with external auditors, different interpretations of Shariah by different scholars and a lack of alternative Islamic financial instruments. The comprehensive research in this paper fills the research gap by specifying the key attributes of considering the future implementation and management of M\&As in broader scopes.
\end{abstract}

Keywords: open innovation; international business administration; sustainable business; corporate culture; diversity; mergers and acquisitions

\section{Introduction and Literature Review}

Mergers and acquisitions (M\&A) are a global phenomenon and have increased significantly in the developed countries. Attention has been given to M\&As particularly since the late years of 1980s, after the massive collapse of firms and failures of business strategies of different globally known companies in different economic regions of the world like the WorldCom (Ashburn, VA, USA), Rothwell Ltd. (Grand Rapids, MI, USA), Enron, Adelphia and Global Crossing etc. The main frequent causes and motivations for mergers and cross border acquisitions in firms lies in three main strategic domains of hubris, synergy and agency.

Synergy incentive implies that the largest component yield/value of the merger of two or more firms must be superior than that of the actual entity [1]. Acquisitions are attributed to competitive 
benefits that come from the pooling of the capital of the two businesses. The net benefits from M\&As are always optimistic and therefore can be said to be synergistic in nature. The agency motivation means that mergers and acquisitions actually happen as they promote the welfare of the acquiring company management to the detriment of the acquirer owners [2]. The hubris hypothesis indicates that administrators create mistakes in assessing target companies and indulge in acquisitions even though there is little synergy. There are several causes, agendas, economic conditions and structural considerations that can be considered all together in conjunction that affect business decisions to participate in M\&As [3]. It should be concluded that these causes and motivations have improved organizational sustainability as the predominant, long-term goal. It is fair to conclude that, even though this is not the reason, the main priority of business managers who make acquisitions, irrespective of their motivations at the beginning, is to maximize tall-term earnings. Even then, this is complicated by several other variables and it can still be very challenging to find discrete statistical calculations of the impact of M\&A on earnings [4]. This posed a greater influence on need to develop mergers and cross border acquisitions. Another important factor that played an important role in increasing the surge of M\&As was the global financial crisis of 2008 that struck the economies hard enough for them to deteriorate. Emerging economies have also witnessed an increasing trend of cross-border M\&As [5]. Implementation of M\&As is indeed a significant consideration for emerging countries as it allows businesses to enter the developed countries through merger and acquisition and is strongly attributable to economic development and growth. The reallocation of capital by the effective implementation strategies of M\&As represents a phenomenal existence of a successful trend in the previous two decades in developed countries including the hyper active European markets. The magnitude of deals in domains of global M\&As touched a peak of more than $\$ 4.0$ trillion in the first quarter of 2019, representing a significant elevation as compared to a similar time period in 2018. The data rankings comprehensively include the mergers, debt-for-equity swaps, divestitures, private placements of common equity and convertible securities, joint ventures, acquisitions and the cash induction component of effective recapitalization all in accordance with the global business standards [6-8]. M\&As can serve as the most effective powerful tools and establish a strong basis for productive growth of corporate and sustainable survival of a business if and only if properly planned and implemented in efficient strategic ways. Using M\&As as a business practice, globally placed firms can be very efficiently merged. By doing so it will be an easy task to reconfigure their businesses which means all their productive assets, useful resources can be readily redeployed, added, recombined and divested in an objective way to fully strengthen up the effective resource base [9]. Failing to correctly perform and implement the M\&As strategies leads to an evident decline followed by a significant decrease in the value of organizations [10]. Effective M\&As are clearly the cases of self-induced concentrations of different enterprises into one-unit entity acquiring united ownership and establishing combined managerial controls of one organization on the other. The definition of a cultural dimension for free innovation dynamics can be assembled as a relationship between the three significant facts of entrepreneurship which can be clarified as the entrepreneurship of new entrepreneurs, the intrapreneurship of workers of an operating firm, as well as the organizational entrepreneurship including the company itself in detailed aspects of mergers in cross border and culture acquisitions [11]. This is actually a complex yet comprehensive transaction existing outside the ordinary business plans and management tactics of the considered firms over a large period of business, fulfilled effectively by a complete agreement that is at large based upon the relevant financial and authentic factual information. Trade and financial liberalization have induced a significantly effective and positive contribution to the firms and markets in the Europe and the European Monetary Union including many other firms belonging to the developed world. There seem to be no clustered stages, according to a variety of reports on open innovation communities that have suggested different attributes and characteristics. Thus, if we again describe an open innovation culture as any characteristic, it would only encourage the fragmentation of an open innovation culture. Since open innovation empowers dynamics mostly in innovation and marketing strategies of established companies, an open 
innovation culture needs to be dynamically described [12]. These cross-border and cross culture M\&As lead the businesses to induce productive synergetic effects, elevate tax savings, acquire the smart discounted assets, offer to access the new technologies and diversify the comprehensive business activities, thereby elevating the standard competitiveness and firm market values thus leading to the sustainability of the business. This trend favors strengthening of the links between developed and emerging countries [13]. The literature on corporate acquisitions indicates that gains to bidder firms in the developed countries are largely insignificant. However, the work against cross-border deals such as cultural differences, information asymmetry and the need for cost sharing between headquarters and international divisions, create agency problems [14]. More broadly, the Gulf Cooperation Council (GCC) region is full of interference and dominance in business firms by the owning strong families; the private sector businesses are affected by the intervention of government, the monarch form of political system and Islamic law based legal systems. There is a very clear difference in multiple aspects between the Islamic and non-Islamic firms. Based upon certain differences in formal culture and the religion structures of two firms belonging to Islamic and non-Islamic firms is indeed a concern to be dealt with for a successful merger. It is evident that the existence of variations in cultural expressions and religious operations can be a significant factor in the successful application and expansion of firms as mergers from GCC countries like Saudi Arabia, Kuwait and the UAE to the developed and sustainable business international borders [15]. It has been argued that cultural and religious differences influence corporate governance practices differently across the globe. An aspect that has received little attention is how religious undertones (in this case, Shariah principles) influence cultural differences and how such differences have hampered cross-border M\&As in the Gulf countries. One of the greatest challenges of the cultural dynamics of the Gulf countries is the potential manifestation of agency behavioral problems due to the absence of uniform and standardized interpretations of Shariah laws/principles. As it currently stands, different scholars can provide a differing range of interpretations. In addition, there are a number of research studies on the varied level of entrepreneurship in companies, that demonstrates the culture of open innovation mechanisms. It would also be helpful to describe the conceptual framework of "Community for Open Innovation Dynamics" focused on the engagement of dynamic entrepreneurship [16]. On the one hand, there is flexibility in interpreting Shariah to suit different circumstances in different countries. On the other hand, this flexibility has the potential to be misused and abused as agents pursue their self-interests. Another problem is the lack of institutional rigor and insufficient business knowledge seen in members of the Shariah Supervisory Board (SSB), which is the architectural hub, so to speak, of the Islamic corporate governance. Other significant factors affecting the level of M\&A activity in the identified Gulf countries stem from the non-conformity of the business and/or operations of some of the foreign companies. As major developments in the Islamic business systems currently focus on financial institutions, we focus on the challenges of M\&As between the Islamic financial companies in three Gulf countries (Saudi Arabia (SA), the UAE, and Kuwait) and foreign non-Islamic financial companies $[15,17]$. We aim to review the foregoing problems and suggest steps for their resolution. The remainder of this paper is set into five parts: the paper proceeds by addressing the Shariah corporate governance in the Gulf countries. Thereafter, we explore the theoretical basis for the behavioral Islamic corporate governance model. Next, we consider how international M\&As are currently undertaken in the identified Gulf countries. The sections that follow provide the methodology, findings and recommendations for improving M\&As with the Islamic companies, while the final section contains the conclusion.

\section{Methodology}

There are many factors (see Figure 1) contributing to the cross-border M\&As, such as (i) the tendency in emerging economies to invest abroad; (ii) creating synergy between or diversifying businesses; (iii) capitalizing on growth opportunities; (iv) harnessing complimentary resources; (v) gaining a larger market share; (vi) establishing economies of scale; (vii) avoiding undervaluation of target firms; (viii) obtaining intangible assets such as know-how and knowledgeable employees; 
and (ix) gaining a degree of freedom not available in their domestic economic environment [18]. The role of these factors vary as different countries may have different principles, procedures and business practices, either explicit or implicit, depending on their cultural, religious and ethical frameworks. These variations may pose challenges for firms' cross-border expansion strategies. Corporate governance in a country is shaped by its culture, history and religion. Religion and social tradition influence organizational behavior, values and ethical perspectives. For example, in the Islamic countries (especially, in the Gulf countries), it is widely assumed that there is no distinction between religious and secular affairs. Clearly, companies in the Gulf region are interested in the cross-border M\&As with companies around the globe. Nevertheless, a major factor that hampers M\&As is the agency problem. The corporate governance model of an Islamic company is crucial in understanding the reasons and sources of potential agency problems that undermine the success of the cross-border M\&As [19].

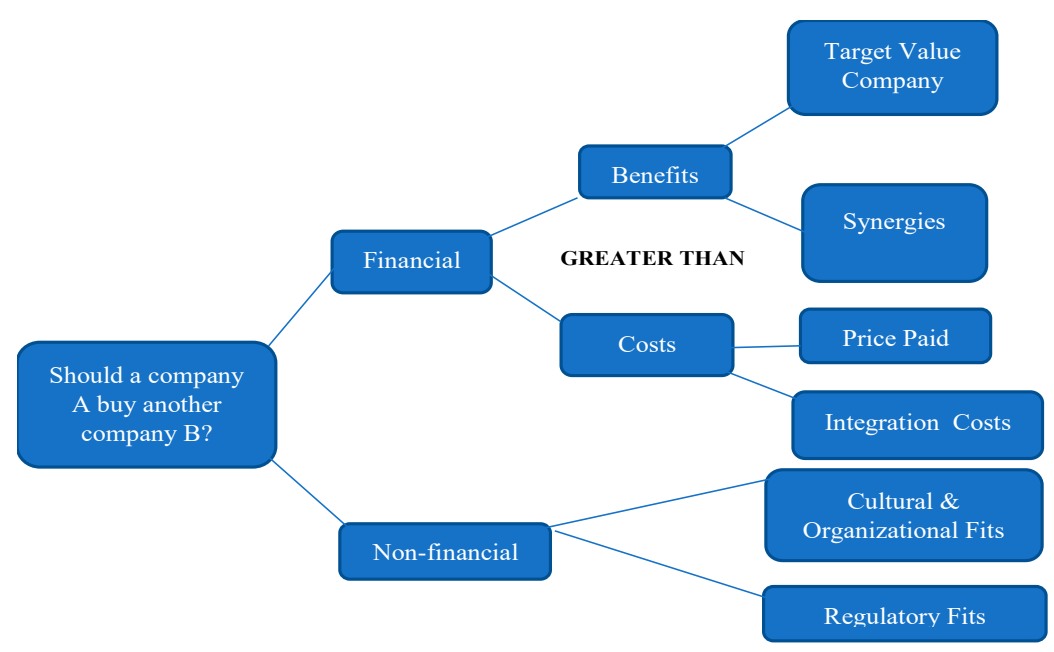

Figure 1. Factors of dependence for mergers and acquisitions (M\&As) between firms.

Cultural clashes have a negative impact on M\&As. Therefore, it is important to understand how the cultural differences influence the success of the cross-border M\&As between the Islamic and the non-Islamic companies. The relevant literature shows that Islam as a religion promotes ethical behaviors in society as there is no existence of any distinction between the religious and worldly affairs [20]. Based upon the themes of cross-border M\&As internationally, the companies in the GCC regions are at an opposite end with respect to the non-Islamic firms in culture, practices and certain business procedures.

The model above links three management theories offering two opposing perspectives on the potential stakeholder behavior in the context of the Islamic company corporate governance and cross-border M\&As. The implementation of Shariah compliance is supported by the Shariah internal auditors to ensure that the SSB's decisions are appropriately carried out. The UAE recently introduced the role of external Shariah auditors to independently confirm Shariah compliance [21]. As decisions are made in the context of novel products and situations, the different layers provide an opportunity for interaction and dialogue. Such a Shuratic process of consensual decision making is allowed and indeed encouraged, as stated in Qur'an in Al-Shura (42:38). In case of externally appointed SSB members who serve on the SSB of multiple companies, there is an opportunity to interact with a diverse range of opinions while solving a broad range of problems. This aligns with consensus building as part of an ongoing Shuratic process. The approach also ensures more uniform Shariah compliance and reinforces the Islamic corporate governance practices. Furthermore, the approach encourages evolving beyond certain instruments that might comply $[17,22-24]$ with the Shariah only superficially, i.e., respecting the letter of the law but not its spirit. 


\subsection{Techniques to the Study}

The main approaches of reasoning and related consequences will also be explained in this section. The approaches adopted which led this study are explained.

\subsubsection{Qualitative and Quantitative Techniques}

When determining an effective research methodology for a particular sample, researchers typically consider the preference between qualitative and quantitative approaches and, where necessary, the use of both. It is necessary to define the significance of the data gathered by choosing an appropriate analysis methodology to be used in the study. It is also important to separate qualitative and quantitative analysis approaches from one another before addressing which analysis is ideally suited to this research.

\subsubsection{Deductive and Inductive Reasonings}

The two main approaches to formulate research questions are: a deductive approach, which means that the researcher continues by going from general thoughts on the specified subject to the creation of precise research questionnaire. From the other side, operating inductively begins with a particular question and progresses from it to create more generalized questions about the topic [25]. This means that researcher conducts a comprehensive review of the existing literature on the chosen subject, and attempts to create theories on the basis of a detailed understanding of the subject. Then on basis of this, the argument would be evaluated on the basis of both the empirical observation of the evidence collected through primary study and the interpreted findings, respectively. The deductive method is also used for quantitative analysis in which hypothesized associations are formed and checked [26]. Conversely, the inductive method yields the theory as the result of the research. This method is also referred to as the "Bottom-Top" method, where analysis begins with concrete implementations or observations that will then be used to progress forward and to establish a wider or more general concept of the phenomena under study [27].

\subsubsection{Relevant Approach}

As this analysis focuses on M\&As through countries with a particular society mindset due to the implementation of Shariah law, which has an impact on the growth of Islamic enterprises and would have an effect on international transactions, especially cross-border M\&A, it can be difficult to implement a deductive approach as Shariah law can never be objective in nature. This analysis typically focuses on a high degree of qualitative research design to analyze how Shariah's principles, like Riba, restricted Islamic financial instruments, Islamic inheritance law and the presence of the Shariah Supervisory Board in Islamic firms could influence transnational M\&A. It might mean the suitability of an inductive research, but there is still a probability that the evidence could still be quantitatively evaluated, which would achieve a balance amongst deductive and inductive methods (see Table 1). This study employed an inductive approach, beginning with basic results of cross-border M\&A and Corporate Governance (CG) from an Islamic viewpoint, which forms the foundation for setting up a general understanding of this concept. The inabilities of the qualitative approach regarding this detailed study and analysis are apparent in the need to answer the research concerns in detail, which does not need any form of quantification or calculation. While this analysis just cannot depend upon a quantitative approach, it is assumed that perhaps the integration of these two approaches would provide this research a true reflection [28]. The researcher used the "Mono-method" which is a qualitative approach, which had been originally developed in the domains of social sciences, with the goal of allowing researchers to resolve sociocultural trends, as described in the literature [29]. Primary data units were gathered via semi-structured interviews with the sample population and evaluated to examine the effect of Shariah on cross-border M\&A in identified Gulf countries. Accessible secondary sources of data were used to obtain information on the Islamic CG, 
comprising written documents, journals, CG guides and any legislative publications focused on the Shariah Rule.

Table 1. Summary of this Research Paradigm.

\begin{tabular}{cc}
\hline Paradigm & Interpretivism (Constructivism) \\
\hline Approach & Inductive \\
Epistemology & Subjective \\
Ontology & Relativism \\
Methods & Qualitative \\
\hline
\end{tabular}

\subsection{Stewardship Theory}

Stewardship theory is utilized in the research process to reach the desired effective objectives. It is an idealistic theory based upon the view that business executives guide the business in a manner that transcends individual gain or self-interest through self-discipline. In the context of an Islamic company, those who are entrusted to ensure Shariah compliance are presumed to act objectively at the highest level of ethical values, as emphasized by Maqasid Al-Shariah and implement compliance in terms of both the letter and spirit of the law.

The SSB parallels the Board of Directors (BOD) and is composed of one or more Islamic scholars, who may be externally or internally appointed to carry out assessment of all existing and newly proposed products, services and operations of the Islamic company [30]. Even from a stewardship perspective, those involved in ensuring the Shariah compliance might not be able to make optimal decisions in the interests of all the stakeholders or fully benefit from the Shuratic process if they lack the sufficient commercial knowledge to fully understand the constraints and opportunities offered by the commercial context of their decisions. In case of the demise of an owner, multiple successors could emerge. (see Figure 2).

\section{Stakeholder's Profit}

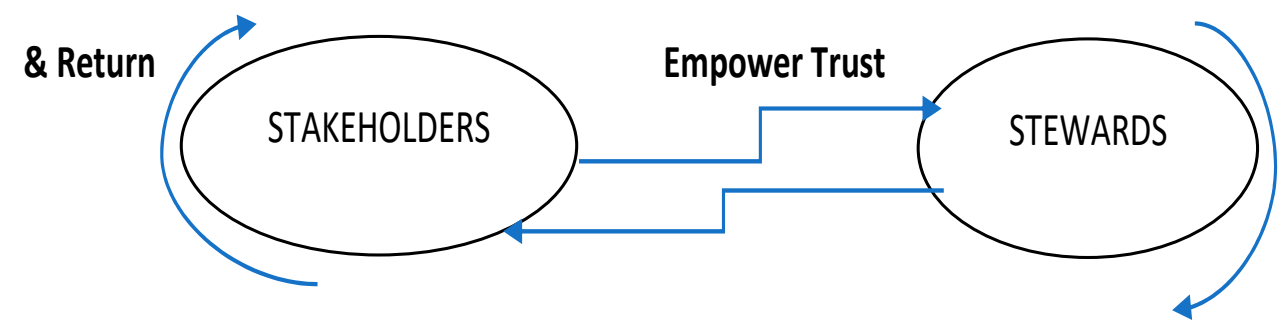

Protect and Maximize Stakeholder's wealth

Figure 2. Operational Relation of Stewards and Stakeholders.

However, under the stewardship perspective, such successors are presumed to act in the best interests of the business and are not likely to pose any challenge other than fragmenting ownership and incurring costs and delays (see Figure 3) [31,32]. A potential problem that could arise from the complex Islamic inheritance law relates to the BOD of the non-Islamic company, which, as a steward for their stakeholders, might find it difficult to contend with the uncertainty of succession, arising from the complex law of inheritance, in case of the demise of an Islamic company owner. On a realistic note, stewardship theory is contested by agency theory, which takes into account the nature of human behavior, especially when managers, as agents of the owners, act to maximize their own gains even at the expense of the owner and other stakeholders. In the comprehensive context of an Islamic company, in addition to the BOD, the SSB also manages the affairs of the company and shares authority over implementing all business strategies, plans, compliance and decisions [33]. To be Shariah compliant, the SSB provides Shariah advisory and consultancy to the BOD in all aspects relating to products, 
services and business transactions. The SSB members can issue a Fatawa on a particular commercial issue, and the advice can be different based on different interpretations of relevant Shariah principles. However, they may have insufficient commercial knowledge and experience, which might affect their decisions. The BOD can influence the SSB members to be favorably inclined towards the BOD's decisions because they determine the consultation fee or remuneration [34]. Since none of this is made public, unlike the BOD, it is difficult to hold the SSB members accountable by ascertaining the originators of the decisions and identifying who could have influenced the decision. This is a weakness in Shariah corporate governance in terms of its level of disclosure and transparency. Due to the limited number of qualified Shariah scholars, SSB members might be working with many companies at one time. The effect of the memberships on multiple SSB might lead to inadequate time to allow for proper analysis and consideration of all relevant issues. This also could lead to hurried decisions, which might not be optimal. Another drawback is the risk of leakage of a company's confidential information to another company by the SSB members, either inadvertently or deliberately for personal gain $[35,36]$. Membership in multiple SSBs might also lead to "group think" behavior, creating a barrier in independently judging situations. There is no regulatory body that provides a code of practice on privacy and sharing of information to inform, govern and penalize the behavior of the Shariah scholars serving on multiple SSBs. Similarly, the possibility cannot be ruled out that external or internal Shariah auditors, who ensure the implementation of Shariah compliance, might collaborate to protect one another's interest. There are few recognized Shariah scholars in the business domain, who are bound to be familiar with one another, and there may also be a pecking order based on reputation, making it difficult to be critical of other scholars' opinions. This can contribute to agency behavior and weaken the Shariah corporate governance model. When new business issues arise or in case of a situation not well defined in the primary sources of Islam the Qur'an and Sunnah, the SSB members can adopt a secondary source of Islam known as Qiyas. Qiyas is a deductive analogy in which the new issue or situation is compared to an existing issue or situation for which there is a ruling based on primary sources and, in case of close similarity, the same ruling is applied. However, the SSB, lacking an understanding of the complexity of the business issues involved, might not be able to fully provide an optimal solution. Moreover, well-experienced SSB members could use this lack of knowledge to justify any agency behavior and offer it as a defense when they are questioned. For example, Zakat is a religious tax that is payable on growing capital and real assets. The payment of Zakat is compulsory in countries such as Saudi Arabia and Kuwait, while it is voluntary in other countries, as in the UAE. The SSB is entrusted with the task of determining the amount of Zakat to be paid. However, the BOD might provide inaccurate financial data to reduce the Zakat, and the SSB members, not having business knowledge, may not be able to challenge it. Alternatively, Shariah scholars may collude with the BOD to disclose a lesser amount of Zakat or somehow lessen the company's financial burden, especially if it is financially unstable. In this case, the SSB members can still offer their lack of business knowledge as a defense. In conventional business, the underpayment of Zakat could be as prevalent as the underpayment of taxes. Thus, the above mentioned comprehensive critical analysis of previous studies demonstrates clearly the fact that induction and practice of mergers within firms of one culture, and one set of business trends with other of an opposite paradigm can offer certain multifactorial effects upon the productivity of firms. These mergers may benefit firms in reallocations, elevations and diversified expansions in business capital. The cultural factors including local working norms, official languages and the international cultural differences are amongst the major outcomes that cause hindrance in cross border mergers especially between the Islamic and non-Islamic states [37]. On account of such cross-border mergers we have another factor prevailing to be an obstacle in the development of mergers that is the concern of leadership factors. Leadership factors from past studies were critically examined and they came out to be the overlapping of leadership roles, the differences in style of leadership that exist in the GCC region countries and the non-Islamic world-based organization. Upon a thorough examination of past findings, we can visibly notice the fact that organizational factors are also significant enough in nature to affect the cross-border mergers 
and acquisitions. The differences in structural nature and setups of different organizations belonging to different markets of globe offer functional divisions, and matrix structures [38]. The differences prevail at large in the human resource setups, reward systems, the effective measurement of Key Performance Indicators (KPI) and other factors must be accounted for. The comprehensively planned research study in this paper fills an important research gap by efficiently identifying and specifying the key attributes for considering the future implementation of M\&As and management in broader scopes of this issue. Given the insufficiency of research on the Shariah-compliant corporate governance and the cross-border M\&As in the Gulf countries, we used a qualitative approach. The researcher purposively selected 15 financial institutions from the selected Gulf Cooperation Council (GCC) countries. The key criterion for selecting banks and insurance companies is that they should be operating in the context of an active M\&A. So, all of the chosen nine banks and six insurance companies from the three GCC countries are those involved in M\&A activity. The choice of these countries is underpinned by their similarity in religion, culture, resource context and the degree of exposure to Western influence. Research on these topics also reflects an interest in applying Shariah law to business and management practices [39]. Often, GCC firms and managers seek to develop modern knowledge, processes, best practices and procedures so that they may better align themselves with the trends of globalization, rendering them more attractive for investment. Semi-structured interviews were conducted, either face to face or over the phone with 40 key individuals including BOD members, lawyers and the Shariah scholars involved with three Islamic banks and two Islamic insurance companies in each of the three selected countries: Saudi Arabia, Kuwait and the UAE (see Table 2) [40]. Each research participant group was interviewed with reference to 20 to 30 questions regarding the effects of the Shariah corporate governance on the cross-border M\&As.

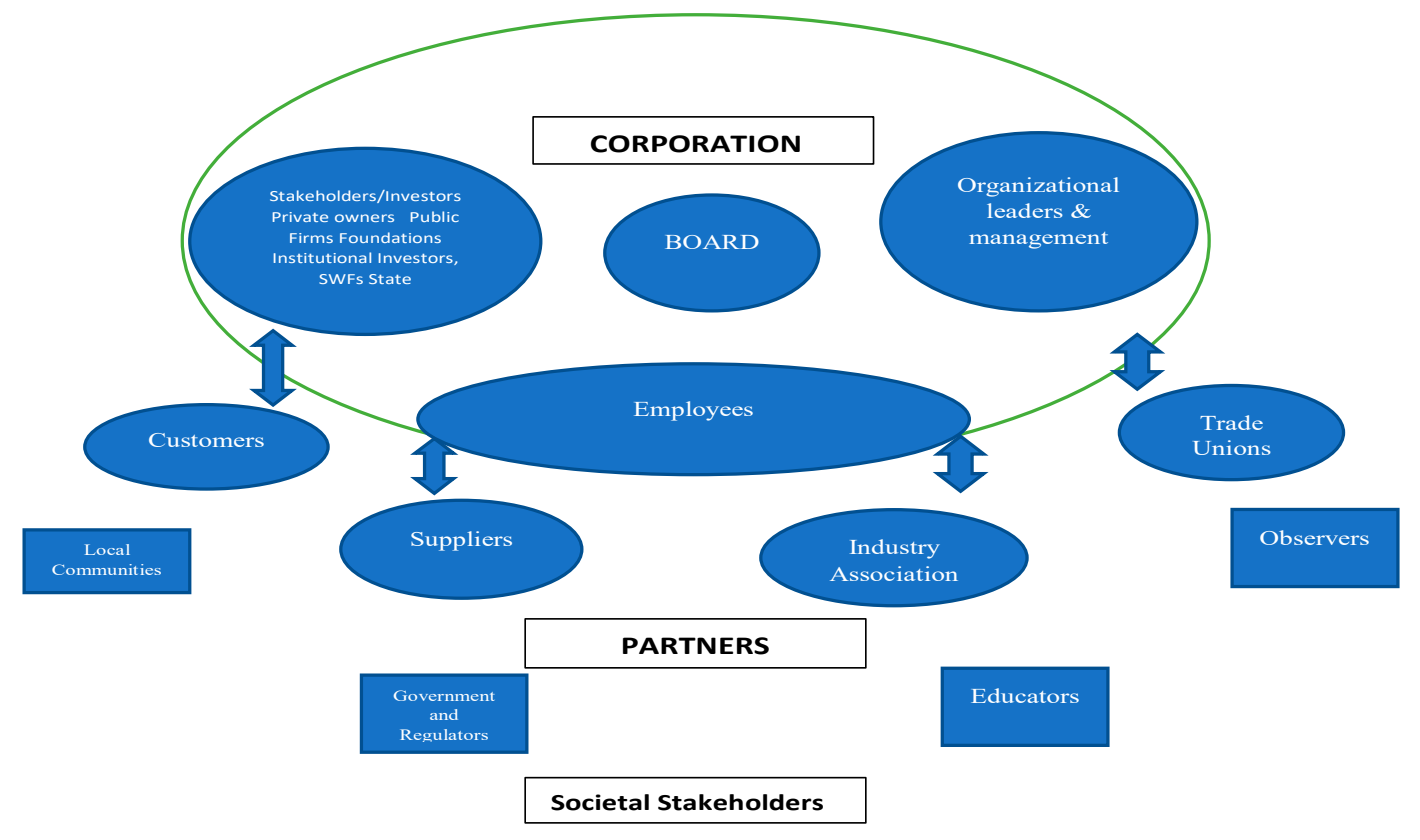

Figure 3. Major players of M\&As.

Table 2. Profile of respondents.

\begin{tabular}{ccccc}
\hline Companies & Saudi Arabia & Kuwait & UAE & Total \\
\hline Banks & 10 & 5 & 7 & 22 \\
Insurance & 7 & 5 & 6 & 18 \\
Total & 17 & 10 & 13 & 40 \\
\hline
\end{tabular}


The sample size ensured that the researcher had a sufficient number of companies and interviewees from different countries within the region. The selected respondents play key roles in organizational decision-making, oversight, and analysis of business environment. Hence, the three groups of interviewees selected for this study could be used to effectively address the research issues under investigation, thus enhancing the credibility and trustworthiness of the findings. For example, legal advisors provide counsel to organizations regarding the laws, rules and regulations, including the Shariah law and principles, which affect business organizations [41]. The Shariah board members and the Shariah scholars, for example, interpret the Shariah law and evaluate compliance. Senior managers help financial institutions to achieve organizational goals. Therefore, the respondents had rich work experience, a thorough knowledge of the context, and their inclusion in the study was vital [42].

\section{Results}

The findings from the interviews suggest that despite the Gulf countries' strong economic ties and shared culture, there was diversity in the application of the Shariah as these countries showed varying degrees of conservatism and orthodoxy. Moreover, some of the interviewees considered it problematic that Shariah scholars varied in the three countries in terms of their demands for compliance, with the UAE being the most liberal and Saudi Arabia being the most conservative. Many interviewees agreed that the interpretations of Shariah by different scholars need to be more uniform, predictable and standardized, thus providing the parties with a greater chance for business success. Most of the interviewees believed that Saudi Arabia and Kuwait had weak systems of disclosure due to insular business practices, while the UAE had a high level of disclosure due to its international engagement. The Islamic inheritance law, which can fracture ownership, allows the addition of family members, who may have insufficient knowledge and experience, to the BOD, creating uncertainty in the ownership structure. This law is also a barrier for non-Islamic companies. The interviewees revealed that there is a lack of alternative Islamic financial instruments to fund M\&As in the Gulf countries, where the most popular Shariah compliant instrument is Sukuk (the Islamic Bond). However, many interviewees believed that such an approach involves a much higher cost compared to the conventional bond $[43,44]$. The key elements that influence governance framework of any nation or organization are trust and honesty. The religious and cultural features of these societies may influence these elements and, in particular, they form an integral part of the Islamic societies which include the Gulf countries. It could be why the respondents were concerned about the religious and cultural aspects of conventional corporate governance [45]. Profit maximization, economic efficiency and fair dealings are valued in all of the three Gulf countries; the respondents believed that corporate activity should also be directed towards adherence to moral standards acceptable to a society. One of the participants emphasized the following: "We exclude everything that opposes Shariah, because our first goal is to satisfy the customers, almost all of whom adhere to Shariah and search for products that are in compliance with the Shariah principles. The success of the insurance company depends on the customer satisfaction and obviously we are working within an Islamic environment". The findings reveal that, despite their strong faith in consonance with the Islam, Islamic countries struggle to adopt these ethical standards. This is because of the Western "secular humanist" influence on business, managerial and organizational systems, which can run counter to those derived directly from Islam. The analysis also showed that the selected Gulf countries could not adopt any conventional code of practice without evaluating the Islamic Shariah principles and local culture. For example, blue-chip companies in the West may find it challenging to adapt to the Islamic principles. The considered countries of GCC can easily modify their corporate governance code of practice, more so than the Islamic companies, which tend to be rigid in terms of implementation [46]. Furthermore, it is nearly impossible for the Islamic companies to adopt conventional corporate governance without considering their Islamic principles and culture. There are aspects where the application of conventional corporate governance principles is closely aligned with those of Islam in the identified the Gulf countries. This is with regards to financial reporting and disclosures. Some of the respondents emphasized that there are varying degrees of disclosure and 
transparency across sectors. For example, the disclosure levels of banks in Saudi are higher than those of the insurance sector. However, in case of Zakat (Islamic tax), both sectors had weaknesses. In the insurance sector, some determinations regarding Zakat are often not fully disclosed to stakeholders. Similarly, the banking sector's level of compliance with transparency policies remains inadequate. This inadequate disclosure could be due to insufficient knowledge on the part of the Islamic banks or cultural factors. Arab culture discourages people from boasting about their wealth, so both private and listed companies prefer not to publish their financial data, which may be seen as a failure to comply with disclosure and transparency rules [47-49]. It is noteworthy that the companies in the UAE view disclosure and transparency as important for carrying out M\&A activities. Experts in this country seem to view M\&As as instruments to achieve a higher level of transparency due to their engagement in an international environment. Some Islamic financial institutions do not fully comply with the business code of conduct as approved by Islamic or conventional corporate governance. This issue may create hurdles in cross-border M\&As because the foreign companies operating in conventional sectors could potentially reveal sensitive information to stakeholders regarding every aspect of the company's operations. The findings further show that for UAE companies, the typical BOD includes members of various nationalities and backgrounds with considerable experience and sophistication. This means that they can provide more experience and knowledge for performing cross-border M\&As effectively. This aligns with the conclusion that Board size and composition have an influence on the firm and its financial performance. It is generally appreciated that independent auditors can help to ensure the integrity of financial information; it should be noted that they are not widely used in the identified the Gulf countries. We found that there are two different types of independent external auditors (Shariah external auditors and conventional external auditors). The UAE has only just recently included the Shariah independent external auditor, while this role still does not exist in SA and Kuwait, which negatively affects the level of disclosure and transparency. In Saudi Arabia and Kuwait, shortcomings have been identified in conventional external auditing that may have resulted from poor communication between the audit committee and external auditors and pressure on independent auditors [50]. This highlights a potential conflict of interest between the external and internal auditors in terms of the decision-making process, especially in how Zakat is calculated so that a company can manage to pay a lower amount of Zakat. It also indicated that the internal auditors may be influenced by management in terms of procedures and principles of best practices and, in turn, they influence the external auditors. Regarding the question of whether the adoption of the Islamic principles can restrict business expansion through cross-border M\&As, the findings show that adopting the Shariah law code limits the scope of business beyond the Muslim countries. One of the respondents described the situation as follows: "Although doing business by following the Islamic principles is good and low risk, it causes difficulties in the cases of restructuring the products (for example, an insurance policy) to comply with Shariah. If the company did not have to worry about this compliance, it would be more flexible in business and would also find more investment opportunities" [51]. Some respondents, experienced with M\&As, stated that the foreign companies doing business with companies from the Islamic countries should engage with them "in a special way" to accommodate the complexities involved in applying the codes of Shariah governance. There are regulatory authorities who oversee the investments of companies in foreign countries and pass their verdict on the legitimacy of such transactions in the context of the Islamic corporate governance. This implies that transactions or practices of the companies regarding cross-border M\&As may affect M\&A activity if any agreement is found to be against the Islamic corporate governance. As the international perspective on the Islamic finance starts assuming significant relevance in the global economy, it is important to find ways to enable both the Islamic and the non-Islamic companies to coexist for the purpose of increasing economic activity and human development in more acceptable ways [52]. 


\section{Discussions}

It is also important to note the different approaches to business dealings among the selected countries and how these decisions may be hampered by cultural values with respect to cross-border M\&As, especially in terms of applying the Islamic principles of corporate governance to non-Islamic companies in non-Islamic countries. It was found that there are different approaches to business dealings between the Islamic companies and non-Islamic companies attributable to differences in culture. The respondents from the banking sector were of the view that Western companies should adopt a different approach in the running of businesses. This would include, for example, taking up loans on interest to expand their businesses. This may limit the capability of investors to expand their businesses through M\&A activity [53,54]. In particular, the findings show that the investors in SA have no investment culture; they have only financial resources pooled up from their relations and families. These financial resources are normally derived from trust-based and interest-free loans. However, there may be a lower limit on how much they are willing to provide compared to a financial institution that bases their decision on the capability of businesses to repay such loans. Such practices can have a negative impact on cross-border M\&As.

\subsection{Open Innovation by $M \mathcal{E} A s$}

M\&As will be an important channel of open innovation for firms in introducing new business models or products, going into a new market, or developing current business models. Thus, the observations suggest that M\&A activity in the identified Gulf countries is complex. This is because of the differences in opinion among the Islamic scholars coupled with the variations in their degree of business knowledge. This can be a major factor that can either restrict or enable cross-border M\&As with non-Islamic companies in Western countries. Nevertheless, there are clear areas in which the Islamic principles are almost uniform. For example, financial instruments such as bonds, swaps, futures, and forwards are not allowed by Shariah in their conventional form and would need restructuring, where possible, to comply with the Shariah principles. For example, Sukuk (Islamic bonds), where the bond is backed by real assets and the return is a fixed share of profit, is always Halal, as opposed to the return being in the form of interest, which is Haram, noting that not everything is explicitly prohibited by the Shariah and that there is room for interpretation [55]. It is essential that foreign companies willing to do business with the Islamic ones reflect their commitment by showing the utmost respect for Shariah laws and principles. It must nevertheless be conceded that Shariah compliance may be a barrier in dealing with non-Islamic companies. Noted that restructuring an Islamic company to accommodate the capital structure of the target company could be cumbersome, time-consuming and costly [56]. In many cases, such restructuring might fail, leading to breakdown or excessive delays in the M\&A process. The process of cross-border M\&A is complex and requires evaluation of a range of business, legal, operational, accounting and tax issues, and a consideration of risks associated with cross-border deals [57]. Shariah compliance adds to complexity and introduces further costs and delays. The Accounting and Auditing Organization for the Islamic Financial Institutions (AAOIFI) provides guidance standards that the Islamic companies can follow in ensuring that they are in compliance. Some organizations completely follow these standards, while others use them as a reference to guide in particular decisions [58]. It is essential that while maintaining the minimum standard provided in guidelines, the Islamic companies should devise innovative methods that enable them to successfully complete M\&As to the same extent as non-Islamic companies. Finally, conflict of interest must be avoided to improve the rate of M\&As in the identified countries [59]. For example, the AAOIFI guidelines require that the SSB appointed members should not hold any shares in the company for which they work. By owning shares in the Islamic companies, they might be tempted to engage in misinterpreting the Shariah principles for the company's benefit rather than ensuring interest-free and Halal principles and working towards socio-economic justice in line with Maqasid Al-Shariah [58,60-62]. Therefore, unifying the interpretation of Shariah business principles may aid in the success of cross-border M\&As by removing uncertainty generated by scholars with 
differing interpretations. The adherence to well-defined corporate governance codes, along with mutual agreement between the merging companies, can guarantee the success of M\&A activity and can stabilize M\&As between the Islamic companies in the Gulf and other non-Islamic companies [63-65].

\subsection{Future Implementation of $M \mathcal{E} A s$}

From the dynamic aspects of future implementations and efficient outputs of mergers of Islamic GCC region firms belonging to KSA, UAE and Kuwait with non-Islamic organizations, a comprehensive orientation is essential in order to clearly focus upon the holistic paradigms of sustainability in cross border businesses. From the future merger questionnaire responses, it is evident that the effective integration of a social, environmental, and sustainable economic atmosphere is a must. A majority of respondents gave full significance to the factors of cultural similarity and business codes to be one of the major obstacles in sustainable cross border mergers. The effects of following role players are evidently conducive in both merger seeking firms

- $\quad$ sociocultural factors;

- global factors;

- human factors.

By inducing global thinking integration between firms for cross border mergers, a sustainable business can be established. The perceptions of the interviewees are consistent with three management theories: stakeholders' theory, stewardship theory and agency theory, as they relate to corporate governance mechanisms including the BOD members, SSB members and auditors who facilitate the cross-border M\&As. However, the respondents revealed key obstacles to the success of cross-border M\&As between the Islamic and the non-Islamic companies such as the need for Shariah compliance (prohibition of Riba or interest, obligation of Zakat or an obligatory contribution based on earnings/wealth and the Islamic inheritance law), weak systems of disclosure, the lack of independence, corruption in compliance, having family members on the Board, weakened communication with external auditors, different interpretations of Shariah by different scholars and a lack of alternative Islamic financial instruments [66-68]. Ultimately, the findings draw important implications for governments, policymakers, Shariah scholars, managers, investors, academic institution, and researchers. The rest of the world has started taking steps towards the global harmonization of corporate governance practices. It is time for the Islamic world to formally standardize the Shariah principles and work towards the harmonization of the Islamic corporate governance.

\section{Conclusions}

The purpose of this study was to investigate the impact of Shariah corporate governance on the cross-border M\&As in three Gulf countries (Saudi Arabia, Kuwait and the UAE), contribute to the literature on corporate governance, and explore the differences in Shariah corporate governance practices and mechanisms within the three Gulf countries. In addition, we add to the research area by investigating the extent to which Shariah corporate governance principles can affect cross-border M\&As between the Islamic companies in the Gulf countries and non-Islamic companies in Western countries with diverse cultures and the study concludes that, for open innovation dynamics, culture is indeed the product of associations between intrapreneurship, entrepreneurship and corporate entrepreneurship [69]. The establishment of the culture for open innovation is imperative not only for business, but also for global regions of development. In the age of globalization, it is important to reconsider how we design our economies on the foundations of the ideals of efficient and sustainable growth. In this respect, there is a need for a culture climate for transparent innovation vibrance in the mergers and cross-border issues for corporate booms [70].

For the first research task, we used semi-structured interviews conducted with 40 respondents who were the members of BOD, lawyers and the Shariah scholars of the selected companies. The questions in the interviews were aimed at eliciting the respondents' views on the objectives of the current study. 
The findings indicate that there is consensus among the respondents regarding how the Shariah corporate governance principles can present barriers for cross-border M\&As.

This study makes five significant theoretical contributions. These are:

- This study contributed to furthering scholarly understanding of:

(1) what constitutes Islamic CG and how it differs from the conventional CG models;

(2) how and to what extent Islamic CG is practiced and its limitations;

(3) compatibility and challenges in accommodating various stakeholders' interests in enforcing shariah compliance;

(4) how issues needed to be considered for successful cross-border M\&A between the Islamic and non-Islamic companies.

- The second contribution of this thesis is the development of the CG model (see Figure 4) which helps to further our understanding of the complex issues involved in the process of cross-border M\&A between Islamic and non-Islamic companies.

- The third contribution of the study is to extend agency, stewardship and stakeholder theories in view of the development of a behavioral Shariah CG model in a critical manner.

- Whilst the stakeholder approach is likely to provide holistic perspectives in informing the expectations, behavior and actions of different stakeholders, agency and stewardship by different interest groups could also play an important role in enabling or constraining the firms' motivation and ability to expand internationally or nationally.

- Fourthly, the study identified gaps in the existing Islamic CG model, in particular the difficulties of knowledge regarding deficiency of the advice provided regarding shariah compliance, underdevelopment of relevant infrastructure, inadequate or limited business knowledge by management, BOD, SSB and Shariah scholars of the Western business context and under defined or emergent legal provisions in support of Shariah principles, low level awareness of the conventional CG and its code of conduct and the possible cause of variations in Shariah compliance which highlighted the difference between the presumed stewardship behavior and the reality of agency behavior.

- The fifth theoretical contribution is what might explain the gap between rhetoric and reality of stewardship and agency problems in the study context.

- This study identified malpractice as the source of a lack of integrity of agents (e.g., corrupt or selfish Shariah scholars or collusion between the BOD and SSB to gain unfair advantages), and such a situation heightens the expectation gap between what is presumed and what can reasonably be presumed for a human being.

This study and research in this field generally, has the limitation of including quantitative analysis that may provide new insight (see Figure 5). Such an approach, which depends on the development of relevant data sets, may be considered in future research. 


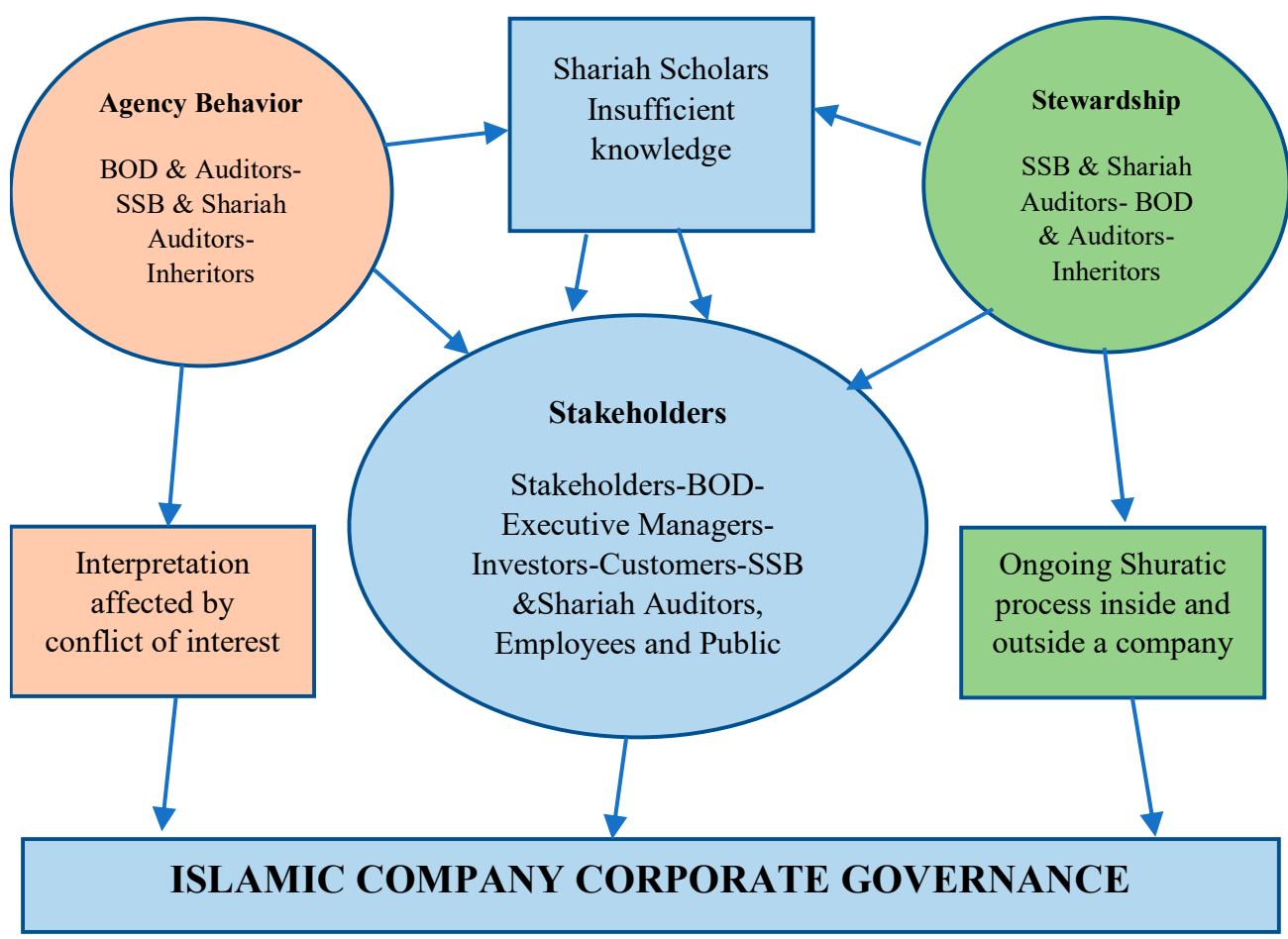

Figure 4. Corporate governance model for an Islamic company [71].

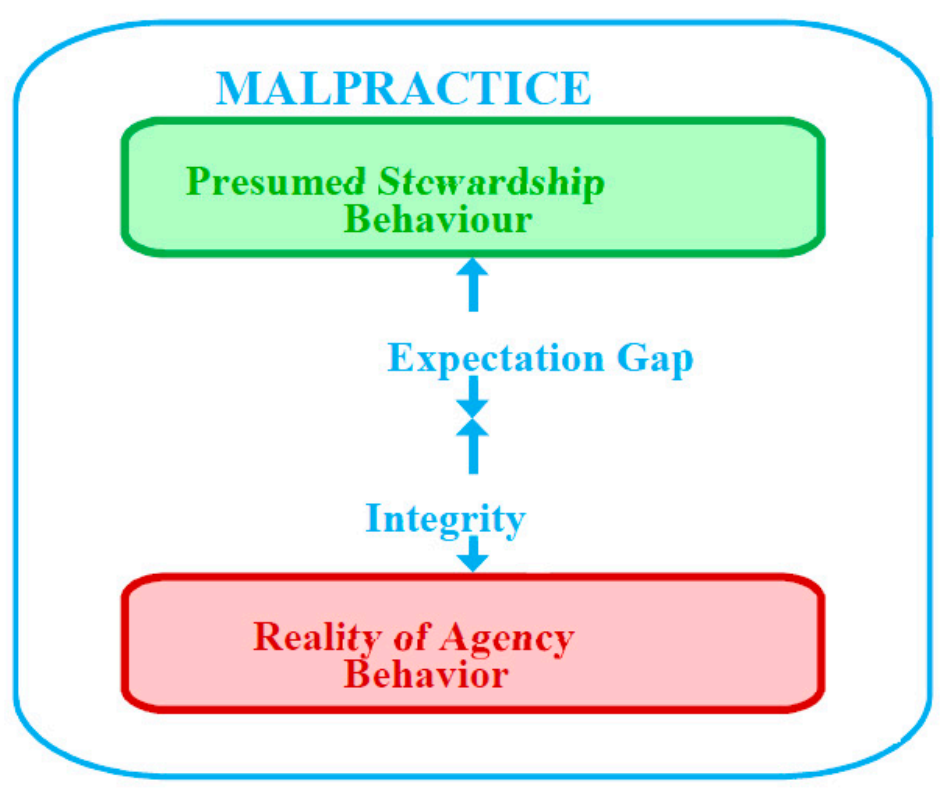

Figure 5. Malpractice.

Funding: This research received no external funding

Conflicts of Interest: The authors declare no conflict of interest

\section{References}

1. Nguyen, H.T.; Yung, K.; Sun, Q. Motives for mergers and acquisitions: Ex-post market evidence from the US. J. Bus. Financ. Account. 2012, 39, 1357-1375. [CrossRef]

2. Kummer, C. Motivation and retention of key people in mergers and acquisitions. Strat. HR Rev. 2008, 7, 5-10. [CrossRef] 
3. Yun, J.J.; Lee, M.; Park, K.; Zhao, X. Open innovation and serial entrepreneurs. Sustainability 2019, 11, 5055. [CrossRef]

4. Florio, M.; Ferraris, M.; Vandone, D. Motives of mergers and acquisitions by state-owned enterprises. Int. J. Public Sect. Manag. 2018, 31, 142-166. [CrossRef]

5. Al-Nodel, A.; Hussainey, K. Corporate Governance and Financing Decisions by Saudi Companies? J. Mod. Account. Audit. 2010, 6, 1-14.

6. Thomas, D.A.; Ely, R. Making Differences Matter: A New Paradigm for Managing Diversity. 1996. Available online: https://hbr.org/1996/09/making-differences-matter-a-new-paradigm-for-managingdiversity (accessed on 11 May 2020).

7. Trapczyński, P.; Zaks, O.; Polowczyk, J. The Effect of Trust on Acquisition Success: The Case of Israeli Start-Up M\&A. Sustainability 2018, 10, 2499.

8. Trompenaars, F.; Asser, M.N. The global M\&A tango: How to reconcile cultural differences in mergers, acquisitions and strategic partnerships. Hum. Resour. Manag. Int. Dig. 2012, 20. [CrossRef]

9. Pollok, P.; Lüttgens, D.; Piller, F.T. How firms develop capabilities for crowdsourcing to increase open innovation performance: The interplay between organizational roles and knowledge processes. J. Prod. Innov. Manag. 2019, 36, 412-441. [CrossRef]

10. Cooke, F.L.; Wood, G.; Wang, M.; Li, A.S. Riding the tides of mergers and acquisitions by building a resilient workforce: A framework for studying the role of human resource management. Hum. Resour. Manag. Rev. 2020, 100747. [CrossRef]

11. Yun, J.J.; Zhao, X.; Jung, K.; Yigitcanlar, T. The culture for open innovation dynamics. Sustainability 2020, 12, 5076. [CrossRef]

12. Christofi, M.; Vrontis, D.; Thrassou, A.; Shams, S.R. Triggering technological innovation through cross-border mergers and acquisitions: A micro-foundational perspective. Technol. Forecast. Soc. Chang. 2019, 146, 148-166. [CrossRef]

13. Wang, Y.; Roijakkers, N.; Vanhaverbeke, W.; Chen, J. How Chinese firms employ open innovation to strengthen their innovative performance. Int. J. Technol. Manag. 2012, 59, 235-254. [CrossRef]

14. Stahl, G.K.; Voigt, A. Do cultural differences matter in mergers and acquisitions? A tentative model and examination. Organ. Sci. 2008, 19, 160-176.

15. Srivastava, S.; Singh, S.; Dhir, S. Culture and International business research: A review and research agenda. Int. Bus. Rev. 2020, 29, 101709. [CrossRef]

16. Yun, J.J.; Liu, Z. Micro-and macro-dynamics of open innovation with a quadruple-helix model. Sustainability 2019, 10, 3301. [CrossRef]

17. Soualhi, Y. Models of Shariah Governance Across Jurisdictions. Islamic Commer. Law Rep. 2016, $2016,22$. [CrossRef]

18. Raman, A.A.; Bukair, A.A. The influence of the Shariah supervision board on corporate social responsibility disclosure by Islamic banks of Gulf Co-operation Council countries. AJBA 2013, 6, 2180-3137.

19. El Gattoufi, S.; Al Muharrami, S.; Shamas, G. Assessment of mergers and acquisitions in GCC banking. Int. J. Account. Financ. 2014, 4, 358-377. [CrossRef]

20. Lzeban, A.; Gwilliam, D. Factors affecting the internal audit effectiveness: A survey of the Saudi public sector. J. Int. Account. Audit. Tax. 2014, 23, 74-86. [CrossRef]

21. Hassan, M.K.; Aliyu, S.; Huda, M.; Rashid, M. A survey on Islamic Finance and accounting standards. Borsa Istanb. Rev. 2019, 19, S1-S13. [CrossRef]

22. Siew, J. Value Creation-as Seen from Asia and Ride-Sharing. Available online: https://www.insead.edu/sites/ default/files/assets/dept/centres/gpei/docs/insead-isp-value-creation-asia-and-ride-sharing-jan-2019.pdf (accessed on 11 May 2020).

23. Sole, M.J. Introducing Islamic Banks into Coventional Banking Systems (EPub); International Monetary Fund: Washington, DC, USA, 2007.

24. Saunders, M.; Lewis, P.; Thornhill, A. Research Methods for Business Students; Pearson Education: London, UK, 2009.

25. Elo, S.; Kyngäs, H. The qualitative content analysis process. J. Adv. Nurs. 2008, 62, 107-115. [CrossRef] [PubMed]

26. Lietz, C.A.; Zayas, L.E. Evaluating Qualitative Research for Social Work Practitioners. Adv. Soc. Work. 2010, 11, 188-202. [CrossRef] 
27. Bernard, A.B.; Redding, S.J.; Schott, P.K. Multiproduct Firms and Trade Liberalization. Q. J. Econ. 2011, 126, 1271-1318. [CrossRef]

28. Silverman, D. Qualitative Research; Sage: Thousand Oaks, CA, USA, 2016.

29. Corti, L.; Bishop, L. Strategies in Teaching Secondary Analysis of Qualitative Data. In Forum Qualitative Sozialforschung; FQS: Berlin, Germany, 2005.

30. Sarala, R.M.; Vaara, E.; Junni, P. Beyond merger syndrome and cultural differences: New avenues for research on the "human side" of global mergers and acquisitions (M\&As). J. World Bus. 2019, 54, 307-321.

31. Rossi, S.; Volpin, P.F. Cross-country determinants of mergers and acquisitions. J. Financ. Econ. 2004, 74, 277-304. [CrossRef]

32. Rottig, D.; Reus, T.H. Research on Culture and International Acquisition Performance: A Critical Evaluation and New Directions. Int. Stud. Manag. Organ. 2018, 48, 3-42. [CrossRef]

33. Othman, R.; Ameer, R. Conceptualizing the duties and roles of auditors in Islamic financial institutions. Humanomics 2015, 31, 201-213. [CrossRef]

34. Rokan, M.K. Optimalisasi peran dewan pengawas syariah (dps) dalam perbankan syariah di medan. Equilib. J. Ékon. Syariah 2018, 5, 292-305. [CrossRef]

35. Qiao, L.; Wu, J. Pay for Being Responsible: The Effect of Target Firm's Corporate Social Responsibility on Cross-Border Acquisition Premiums. Sustainability 2019, 11, 1291. [CrossRef]

36. Reuer, J.J.; Shenkar, O.; Ragozzino, R. Mitigating risk in international mergers and acquisitions: The role of contingent payouts. J. Int. Bus. Stud. 2003, 35, 19-32. [CrossRef]

37. Ouyang, S.; Li, Y. Li Confucius Institute and the Completion of Chinese Cross-Border Acquisitions. Sustainability 2019, 11, 5088. [CrossRef]

38. Piesse, J.; Strange, R.; Toonsi, F. Is there a distinctive MENA model of corporate governance? J. Manag. Gov. 2011, 16, 645-681. [CrossRef]

39. Najeeb, S.F.; Ibrahim, S.H.M. Professionalizing the role of Shari'ah auditors: How Malaysia can generate economic benefits. Pac. Basin Financ. J. 2014, 28, 91-109. [CrossRef]

40. Khalid, A.A.; Haron, H.; Masron, T.A. Competency and effectiveness of internal Shariah audit in Islamic financial institutions. J. Islam. Account. Bus. Res. 2018, 9, 201-221. [CrossRef]

41. Oak, S.; Dalbor, M.C. The Impact of International Acquisition Announcements on the Returns of U.S. Lodging Firms. J. Hosp. Financ. Manag. 2009, 17, 19-32. [CrossRef]

42. Muammar, A.N.; Widodo, J.; Sulhadi, S. Evaluation of zakat management program in the badan amil zakat national of banten province. J. Res. Educ. Res. Eval. 2018, 7, 19-28.

43. McGuire, S.T.; Omer, T.C.; Sharp, N.Y. The impact of religion on financial reporting irregularities. Account. Rev. 2012, 87, 645-673. [CrossRef]

44. Moeller, S.B.; Schlingemann, F.P. Global diversification and bidder gains: A comparison between cross-border and domestic acquisitions. J. Bank. Financ. 2005, 29, 533-564. [CrossRef]

45. Al Naeemy, T.M.Y. Consequences of Mergers and Acquisitions and Their Effect on Employees: A Case Study from the Banking Industry in the UAE. In Human Capital in the Middle East; Springer: Berlin, Germany, 2020; pp. 179-223.

46. Maswadeh, S. A Compliance of Islamic Banks with the Principles of Islamic Finance (shariah): An Empirical Survey of the Jordanian Business Firms. Int. J. Account. Financ. Rep. 2014, 4, 169. [CrossRef]

47. Lewis, M.K. Principles of Islamic corporate governance. In Handbook on Islam and Economic Life; Edward Elgar Publishing: Cheltenham, UK, 2014.

48. Licht, A.N.; Goldschmidt, C.; Schwartz, S.H. Culture, Law, and Corporate Governance. Int. Rev. Law Econ. 2005, 25, 229-255. [CrossRef]

49. Maali, B.; Casson, P.; Napier, C. Social reporting by islamic banks. Abacus 2006, 42, 266-289. [CrossRef]

50. Koldertsova, A. The Second Corporate Governance Wave in the Middle East and North Africa. OECD J. Financ. Mark. Trends 2011, 2010, 219-226. [CrossRef]

51. Karim, S.; Capron, L. Reconfiguration: Adding, redeploying, recombining and divesting resources and business units. Strat. Manag. J. 2016, 37, E54-E62. [CrossRef]

52. Botis, S. Mergers and Acquisitions in the International Banking Sector; Bulletin of the Transilvania University of Braşov: Brașov, Romania, 2013; Volume 6.

53. Iqbal, Z.; Mirakhor, A. An Introduction to Islamic Finance: Theory and Practice; John Wiley \& Sons: Hoboken, NJ, USA, 2011; Volume 687. 
54. Kammer, A.; Norat, M.; Pinon, M.; Prasad, A.; Towe, C.; Zeidane, Z. Islamic Finance: Opportunities, Challenges, and Policy Options; International Monetary Fund: Washington, DC, USA, 2015.

55. Hečková, J.; Štefko, R.; Frankovský, M.; Birknerová, Z.; Chapčáková, A.; Zbihlejová, L. Cross-Border Mergers and Acquisitions as a Challenge for Sustainable Business. Sustainability 2019, 11, 3130.

56. Hečková, J.; Frankovský, M.; Birknerová, Z.; Chapčáková, A.; Zbihlejová, L. Analysis of the Post Merger and Acquisition Process of Implementation of the Cross-border Mergers and Acquisitions by Means of the pDM\&A Methodology. J. Manag. Bus. Res. Prac. 2017, 9, 26-34.

57. Hečková,J.; Chapčáková, A.; Badida, P. Aktuálne problémy ohodnocovania podnikov pri fúziách a akvizíciách a ich riešenie. Ekon. Časopis J. Econ. 2014, 7, 743-766.

58. Georgieva, D.; Jandik, T.; Lee, W.Y. The impact of laws, regulations, and culture on cross-border joint ventures. J. Int. Financ. Mark. Inst. Money 2012, 22, 774-795. [CrossRef]

59. Öberg, C. Acquisitions and open innovation-a literature review and extension. In Mergers and Acquisitions, Entrepreneurship and Innovation; Emerald Publishing Limited: Bentley, UK, 2016; pp. 31-58.

60. Eckbo, B.E.; Thorburn, K.S. Gains to Bidder Firms Revisited: Domestic and Foreign Acquisitions in Canada. J. Financ. Quant. Anal. 2000, 35, 1-25. [CrossRef]

61. Farook, S.; Farooq, M.O. Sharī‘ ah Governance, Expertise and Profession: Educational Challenges in Islamic Finance. ISRA Int. J. Islam. Financ. 2013, 5, 137-160. [CrossRef]

62. Garas, S.N.; Pierce, C. Shari'a supervision of Islamic financial institutions. J. Financ. Regul. Compliance 2010, 18, 386-407. [CrossRef]

63. Brammer, S.; Williams, G.; Zinkin, J. Religion and attitudes to corporate social responsibility in a large cross-country sample. J. Bus. Ethics 2007, 71, 229-243. [CrossRef]

64. Buch, C.M.; Delong, G. Cross-border bank mergers: What lures the rare animal? J. Bank. Financ. 2004, 28, 2077-2102. [CrossRef]

65. Alam Choudhury, M.; Alam, M.N. Corporate governance in Islamic perspective. Int. J. Islam. Middle East. Financ. Manag. 2013, 6, 180-199. [CrossRef]

66. Ali, A.J.; Al-Aali, A.Y. Marketing and Ethics: What Islamic Ethics Have Contributed and the Challenges Ahead. J. Bus. Ethics 2014, 129, 833-845. [CrossRef]

67. Al-Shammari, B.; Brown, P.; Tarca, A. An investigation of compliance with international accounting standards by listed companies in the Gulf Co-Operation Council member states. Int. J. Account. 2008, 43, 425-447. [CrossRef]

68. Ayub, M. Islamic Finance: Laying Down an Overarching Schema for Value based Sharī 'ah Advisory and Governance Framework. J. Islam. Bus. Manag. 2013, 219, 1-64. [CrossRef]

69. Elmquist, M.; Fredberg, T.; Ollila, S. Exploring the field of open innovation. Eur. J. Innov. Manag. 2009, 12, 326-345. [CrossRef]

70. Santoro, G.; Ferraris, A.; Winteler, D.J. Open innovation practices and related internal dynamics: Case studies of Italian ICT SMEs. EuroMed J. Bus. 2019, 14, 47-61. [CrossRef]

71. Bindabel, W.A. The Influence of Shariah (Islamic principles) Corporate Governance on Cross-Border Merger and Acquisitions Involving Islamic Companies in the Gulf Countries. Ph.D. Thesis, Law De Montfort University, Leicester, UK, June 2017.

Publisher's Note: MDPI stays neutral with regard to jurisdictional claims in published maps and institutional affiliations.

(C) 2020 by the author. Licensee MDPI, Basel, Switzerland. This article is an open access article distributed under the terms and conditions of the Creative Commons Attribution (CC BY) license (http://creativecommons.org/licenses/by/4.0/). 